\title{
The Western Balkans Between Statehood and Integration
}

\section{Mehmet Elezi *}

The current threats to European security no longer come from within the continent. Friendship, partnership, and collaboration have now taken the place of interstate confrontation. Some tense issues exist, such as the Basque problem, the Irish problem, Kaliningrad, Transdniestria, etc., but they are largely isolated. The Cyprus crisis, silent since about thirty years, has represented a potential danger that extends over the entire island, but it seems like this issue is moving towards a solution as well.

There is another region that is calm for now, but not yet definitively: Southeastern Europe. At various times during the last century this region has been a threat to the security of the continent, causing headaches even in the major European capitals. If the assassination of Duke Ferdinand by Gavrilo Princip in Sarajevo sparked off World War I, the siege of Sarajevo has become a nightmare for the continent and the international community. Can this dramatic cycle be considered completely closed? One thing is for sure: one cannot speak about achieving security in the continent without calming its hot spots, such as Southeastern Europe. The intervention of NATO in Kosovo in 1999, the Stability Pact, and the attention of Washington and Brussels to the progress of the Euro-Atlantic integration of the region are historical steps in this direction.

This region has mainly suffered from ethnic conflicts. Besides the human tragedies, they have lost a great deal of time and have delayed the region's integration into the Euro-Atlantic security framework. But it is this integration itself that is a decisive factor for the prevention of conflicts. Thus, a vicious circle has been created. Therefore, the path of the Western Balkans toward Euro-Atlantic integration is longer than it seems.

Aside from the lack of democratic standards, there is still one more obstacle to the integration of the region. This quite specific obstacle relates to the process of state formation. The majority of the countries of the region have not completed the circle of statehood. In other words, they are not as yet consolidated states with clear and defined boundaries. Their claims for integration into NATO and the EU without being states with clearly defined borders do not look extremely mature.

The combined state known as Serbia and Montenegro has a temporary status. This means that even the individual status of each state-Serbia and Montenegro-is temporary. After the nationalists' return to power, and with burning social and economic domestic problems, everything in Belgrade is more complicated than it was two years ago. Bosnia and Herzegovina is not yet a functional state. The Serbian republic of Bosnia is more influenced from Belgrade than from Sarajevo. There are voices in favor of reviewing the Dayton agreement. Kosovo has a provisional status as an international protectorate. Until recent months, the formula "standards before status" has been foggy and undefined. Eight points of the so-called Grossman plan have clarified what is to be done, but the violent riots that took place recently have created new difficulties. Mace-

\footnotetext{
Mehmet Elezi is Director of the Institute of International and Strategic Studies.
} 
donia is a country with defined state sovereignty, but it can only be described as shaky. The crisis in spring of 2001 clearly showed this.

The only countries that do not have statehood problems in this part of the region are Albania and Croatia, but they are very sensitive in this regard. Being neighboring countries, as well as both kin states and host states, they have to cope with the impact of changes to any boundaries.

The four wars that drenched the territory of former Yugoslavia with blood had an ethno-nationalist motivation. After the establishment of peace, the mentality of some ethno-nationalist politicians has adapted itself like a virus, but it has not been defeated. In illustration of this point, there are two notable "M's" of evidence.

The first " $M$ " is called Mitrovica. Mitrovica is a divided town in Kosovo. This division is specific: it does not start from the bottom up, but the other way round. The division of Mitrovica and the development of Serbian parallel institutions are sponsored by Belgrade. Belgrade requires this state of affairs in order to play the populist nationalist card within Serbia to distract public attention from internal problems. But it needs this situation even more as a card for concessions when the final status of Kosovo will be discussed. In the case of the independence of Kosovo, Mitrovica can be used in two ways.

One way is to maintain Kosovo within its present borders, as provided by resolution 1244, which means that the territory of Kosovo cannot be expropriated. In this instance, Kosovo would serve as a regional model of the democratic integration of minorities in the country's life. Skopje, as a vulnerable neighbor, declared that this solution would not destabilize Macedonia. The violent acts of the past year, which represented a setback, raised some question marks, but the general opinion is that they do not close off the prospects for a multiethnic society. The UN administrator Harry Holkeri declared on 9 April that those acts are not representative of Kosovo society. According to him, they only represent some elements that have their own schemes for the future of the country.

The other way that Mitrovica can be used is to transfer North Mitrovica to Serbia, which means division of Kosovo; or, in other words, the legalization of a situation that already exists in practice as a fait accompli. The Serbian nationalists are trying to make use of recent outbursts of violence for this purpose. The process of cantonization on which Prime Minister Kostunica is insisting is being looked at as a new step towards the division of Kosovo. Judging from the point of view of values, such solution would be a step backwards. It would represent the triumph of the concept of the ethnic state over the integrating concept of a multiethnic society.

In practice, the consequences are more complicated. The division of Kosovo would have a boomerang effect for Serbia itself. According to the same principle, the Presheva Valley, a part of Serbia with an Albanian majority, would demand to join Kosovo. Vojvodina and Sanjak would react according to the same principle as well. Serbia could hardly demand that a double standard be applied to these areas. The division of Kosovo would be both an opening of a Pandora's Box and a time bomb. The whole region could become embroiled via the domino effect. The Bosnian Serbs would 
demand union with Serbia, and the Albanians of Macedonia would in turn take a stand against the stability and unity of their state.

So the precedent of Mitrovica could pave the way to a reaction leading to other divisions. According to the American analyst Patrick Moore, "the problem-or virtueof partition is that it would most likely involve not just Kosovo but every state in the region ... if carried to its logical conclusion, partition would mean setting up a Greater Serbia, Greater Albania, Greater Croatia, and smaller Muslim and perhaps Macedonian states. Montenegro would go it alone, as may happen in any event."

The second "M" is Macedonia itself. The crisis in this country appeared to be a collision between the concept of democratic coexistence and the concept of ethnic domination. The democratic alternative for a Macedonian multiethnic society is being strongly promoted by the international community, but the concept of ethnic domination is still active. It is represented by the opponents of the Ohrid Agreement. It seems that they are working toward division of the country. Their aim to divide the country seems suspect, even as far as the long-term interests of the Macedonian Slav population are concerned. Why?

At first glance, the main problem for Skopje is the Albanian population of Macedonia, although the institutional demands of the Albanians so far have not gone beyond equality in conformity with standards widely accepted by the international community. But Macedonia has unresolved issues with all of her neighbors. Belgrade does not recognize the Macedonian Church. Sofia recognizes the state, but does not recognize the Macedonian nation and language. Macedonia has problems with Athens, regarding the national symbols, her name, and the flag.

A little more than a million Macedonians in the remnants of a divided country would face the risk of losing their national, linguistic, cultural, and religious identity. The violation of this identity would jeopardize the sovereignty of these fragment states as well. That would be the main national challenge raised by a possible Macedonian division, even if such a division were carried out peacefully. Protecting Macedonia as a multiethnic and democratic society is today the only way to preserve the sovereignty and pursue the Euro-Atlantic integration of this country. It is also a crucial step for the region's stability as well.

Some politicians and analysts see the reconfiguration of Southeastern Europe according to the principle of ethnic states as a specific recipe for its long-term stability. This is the case because they are influenced by the experience of the bloody wars and the complex composition of the region. But they also consider the break-up of the former Soviet Union, Czechoslovakia, etc., seeing state fragmentation as a tendency of our age. As Patrick Moore points out, "such observers argue that the future lies with ethnically based partition whether one likes it or not, and that it would be best for all concerned to get the matter over with sooner rather than later." An internationally reputed personality who knows this region quite well-Lord Owen-spoke long ago about this idea. Carl Bild is also a near-supporter of this view.

Maybe seen from the perspective of realpolitik, such a scenario would be a pragmatic approach to achieving long-term regional stability. But nobody has given an answer to the question, Can this recipe be implemented without repeating the sinister 
tragedies of the past? What is described as the exchange of territories and populations is simply a euphemism for ethnic cleansing. That is why the Oxford professor Noel Malcolm, the author of two very much appreciated books about Bosnia and Kosovo, calls this "a terrible idea."

Once again taking the realpolitik point of view, maybe it is necessary to pay a bill for the peace and security of the future generations, and perhaps it is a price that cannot be avoided. But how can we diminish its cost and keep everything under control in a problematic part of Europe that is traditionally considered a powder keg? That is the question.

The dilemma - integration or ethno-nationalism, the product of the vicious circlehas only one answer: integration. The potential benefits of integration could serve as a carrot. It may help to finish the process of state-formation for those countries where this process has not concluded yet. This will require a culture of compromise for all the parties, which is not typical of the region. It will also facilitate the task of emancipating the political class, especially in the countries with an aggressive tradition and indicators of ethno-nationalism. In parallel with this should be the promotion of democratic reforms.

The effectiveness of this formula can be seen in the common commitment of Albania, Croatia, and Macedonia in the framework of the Adriatic Charter. They have strong support from Washington and Brussels to fulfill the standards to join NATO, probably in 2006.

As for Albania and Croatia, as I have already mentioned, they do not have statehood problems. But both of them (and especially Albania) have problems with the consolidation of democratic institutions, improvement of reforms, and fighting corruption and organized crime.

When political scientists want to give a definition of democracy, they summarize: democracy means a free vote, plus more democracy. So the key problem for Albania is the organization of free and fair elections. In previous years, Albania has had bad experiences in this regard, but if the violation of the electoral will is repeated, there is no more democracy. Under such circumstances, it will be impossible to carry out genuine reforms, to really fight illicit trafficking, corruption, and crime. The prospects for NATO integration become foggy. A government that is the result of an electoral fraud can not be part of the regional solution. On the contrary, it is part of the problem, or is the problem itself. 